\title{
CREATIVITY OF HUMAN AND NON-HUMAN MATTER INTERWOVEN: AUTONOMOUS SENSORY MERIDIAN RESPONSE VIDEOS IN A POSTHUMAN PERSPECTIVE
}

\author{
Joanna ŁAPIŃSKA (D) \\ Independent researcher \\ Received 8 December 2019; accepted 18 March 2020
}

\begin{abstract}
The problematization of the idea of creativity resulting in the revision of concepts about autonomous, creative, and human self has been a reality since the end of modernism, or maybe even longer. Postmodernism, as well as theories of posthumanism and new materialism, dealing with categories such as materiality, virtual reality, transgression, hybridization, etc., offer some reflections on the idea of non-human creativity, which is no longer an attribute immanently assigned to human, but a result of interaction between human and non-human elements, including the affective friction of bodies made of matter. Mostly inspired by the theories and methodologies of posthuman studies, studies in new materialism, and new media studies, the article aims to answer the question about the types of creativity appearing in a new YouTube phenomenon - autonomous sensory meridian response videos massively published in recent years. The article is an attempt to give a comprehensive account of the idea of posthuman creativity - with its sub-types like sensual creativity or techno-creativity - visible in extremely popular, however under-researched, autonomous sensory meridian response artworks. The paper puts forward the thesis about autonomous sensory meridian response being a model artistic phenomenon in which the entanglement of human and non-human matter results in a form of posthuman creativity. Numerous examples of autonomous sensory meridian response videos have been analysed, pointing to the specific modes of creative collaboration of human and non-human elements on the film set. In conclusion, it has been shown that autonomous sensory meridian response artworks become the product of posthuman creativity resulting from mutual, affective interaction of bodies.
\end{abstract}

Keywords: autonomous sensory meridian response, new materialism, new media studies, posthuman creativity, posthumanism, techno-creativity, YouTube.

\section{Introduction}

Is creativity a solely human quality? Traditional humanistic discourse, anthropocentrically focused on the mind-endowed human being as the "crown of all creation", sees creativity as something that belongs inherently to human beings and sets them apart from a machine that "can never do anything really new", as Ada Lovelace is believed to have commented on the Charles

*Corresponding author. E-mail: joannalapinska87@gmail.com

This is an Open Access article distributed under the terms of the Creative Commons Attribution License (http://creativecommons. org/licenses/by/4.0/), which permits unrestricted use, distribution, and reproduction in any medium, provided the original author and source are credited. 
Babbage's Analytical Engine (Turing, 1950, p. 450). The analytical engine has no pretentions to "originate anything" (Turing, 1950, p. 450); it can only follow the instructions of a man who must also know how to give them to it - so as to achieve the desired result. Such a machine can neither take us by surprise nor do something really original - something that would not be a result of a human factor. Therefore, it leaves no room for something like creative invention.

In his famous paper published in Mind in 1950, Alan Turing refuted that argument, which he referred to as "Lady Lovelace's Objection" - he agreed that machines are limited by their programmed activities, but he also reminded us that humans operate within a specific program as well (which is conditioned by the person's build, genes, knowledge, and cultural baggage, among others). If you imagine a powerful machine with enormous capabilities, its operational limitations will resemble human limitations rather than limitations of the simple programs of that time. Therefore, as early as in the 1950s, the area of research on computing machines, later simply called "computers", was where people would notice a potential problematization of the concept of creativity as a solely human quality that could not be attributed to human creations.

The last thirty years or so, i.e. the heyday of developing various concepts aimed at destroying the centuries-old wall of humanism and knocking the arrogant Man off his pedestal, have seen an unprecedented, very strong problematization of the idea of creativity as a solely and immanently human quality. In addition, the rapid development of technology in the 20th and 21st centuries contributing to the existence of our reality of products-beings of an indeterminate ontological status, falling outside the familiar divisions into "living" and "dead", "human" and "non-human", "artificial" and "natural", led to the revision of many humanistic concepts of the autonomous, creative self. This coincided with the period known by contemporary commentators as "postmodernism" - defined by the end of the great narratives about Man and described by such categories and ideas as virtual reality, mutation, transgression, hybridization, post-biology, post- and transhumanism, which show a new vision of the world and our place in it, as well as new concepts of art, which is important in the context of the transformed understanding of the idea of creativity (Kluszczyński, 2013).

Postmodern understanding of the idea of creativity is distinctly different from the one suggested by the previous era (modernism) which, having discovered an individual personality characterized by self-determination and the prerogative of autonomy, appreciated both its creative potential and the ability to dominate and shape the subordinate matter that is part of our world. Needless to say, "subject" in modernism can only refer to a human subject that can creatively control matter (non-humans) in the surrounding reality. Pickering (2008a) managed to illustrate this contrast of two separate approaches to the world, using the works of Dutch painters: Piet Mondrian and Willem de Kooning. According to the British philosopher, abstract images of the former painter are rooted in the modernist mode of thinking - they emphasize the duality of humans and things, with humans having the power to control matter (thanks to the gift of reason) and are seen as beings practically independent of the world. According to Pickering, the other concept of worldly existence can be found in the "never finished" works of Kooning. Their posthumanist ontology would be based primarily on the coexistence of human and non-human factors, 
rather than human rational involvement in the world. The artist's (called "the discoverer" by Pickering) paintings seem to have no center and the painter himself is only a co-creator of their art which is seen as "a joint product of the human and the nonhuman" (2008a, p. 2).

Roudavski and McCormack (2016) briefly outlined the contemporary scientific concepts of (non)human creativity present in various research fields where the understanding of "creativity" differs from the one present by postmodern age. As we may reckon, the research panorama of the fields fascinated by the concept of creativity is very vast, including such different areas as new materialism, speculative realism and object-oriented philosophy, posthumanism, science and technology studies, multispecies ethnography, post-environmentalism, to name a few (Roudavski \& McCormack, 2016, p. 3). Conceptual potentials of the theme of creativity present in above-mentioned fields cannot be overestimated. For the purposes of this article, however, only selected concepts derived from the posthumanism and new materialism areas of research will be discussed in details and further applied while analyzing selected autonomous sensory meridian response (ASMR) artworks.

Transgression and hybridization, which are characteristic of postmodern times and inherent in many posthumanist concepts, have been conducive to the newly emerging concepts of creativity. The possibility of extending human experience by crossing the existing boundaries between different zones that have been separated (e.g. between what is "human" and what is "machine", etc.) can trigger a new quality of human creativity, but also lead to dehumanization of the concept of creativity and the idea of "posthuman" (Kluszczyński, 2013) or "posthumanising" creativity (Chappell, 2018), "techno-creativity" (Brett, 2006) or creativity of the matter (Hood \& Kraehe, 2017). Importantly, these concepts are usually formulated when discussing new art genres that defy modernist definitions or hybrid artistic and multimedia works and directions of development of artistic and creative education.

"Posthuman" is sometimes interpreted in this context as "the meeting point of humans and machines that reconfigures humanistic conceptions of the autonomous, creative self" (Brett, 2006, p. vii). According to J. Thomas Brett, posthuman creativity in that sense becomes a quality that does not belong to the human artist anymore, it is not assigned to them a priori, but it is something that is born out of a meeting of various human and non-human elements (such as technological factors in the case of electronic music created by artists using different equipment, software, tools, instruments - in short, different machines). This type of techno-creativity is a result of the cooperation between man and technology (in the cases studied by Brett - electronic and digital music techniques) and its name itself highlights the importance of a non-human element that holds a very important place in that assembly, right next to the human element.

Hood and Kraehe (2017) look at creativity (not human creativity, but the creativity of matter) in a similar way when they describe it in the context of art education, while embedding it more strongly within new materialism (NM), especially close to the idea of understanding things as elements characterized by vitality associated with the nature of materiality that is not always easy to grasp by man. In addition, the researchers follow Bennett (2010) and emphasize the value of so-called thing-power and distributive agency, i.e. the acceptance of the fact that material bodies never act alone and their agency is characterized by interbeing and interdependency. According to Hood and Kraehe (2017), recognizing the fact that we 
are all made of matter and paying closer attention to the creative potentialities of all matter (both human and non-human) is the direction that researchers, teachers, and artists should take in their future explorations and projects.

The idea of posthumanising creativity demonstrated by Kerry Chappell aims to take into account a wide range of creative non-human "players" - "other-than-humans" actants - and, as a result, overcome the limiting and too narrow humanistic conceptualizations of the problem of creativity - in order to constantly provide chance of "creatively living with the changes and challenges of technology, relationships and sustainability, and of 'becoming' in relation to those changes" (2018, p. 295), or chance of a holistic change in the ethics regarding our existence in a world inhabited by humans and non-humans. Posthumanising creativity emerges from the tangle of activities of various human and other-than-human players and allows us to rethink our role and influence on reality - in order to promote the symbiotic co-existence of various components of the world.

This article explores a new cultural and artistic phenomenon known as ASMR, expressed in the works of ASMR artists (so-called "ASMRtist"), i.e. videos published mainly on YouTube - as part of the inspirational paradigm of non-human, posthuman creativity recognized by the aforementioned researchers. It puts forward the thesis about ASMR being a model artistic phenomenon in which the entanglement of human and non-human matter results in a form of posthuman creativity. The work of ASMRtists is seen here as an example of artistic activity involving both human and non-human elements, situated at the intersection of the practical aspect of human creativity, perceiving and appreciating the creativity of matter and the means of technology, while ASMR videos are seen as an example of artistic works resulting from the interlocked activities of both types of creativity, a product of their intertwining activities. The author places this phenomenon primarily in the context of NM and posthumanism, while seeing these philosophical trends as inter-corresponding on multiple planes of interest, including the interpretation of the creative quality as non-inherent to the human subject, but being the result of a combination of various factors, and especially the activity of non-human matter combined with human activities. The author's interpretation sees ASMR as a phenomenon that enhances the significance of matter in artistic work and notices its creative participation in the production of a given work of art that cannot be overestimated. The theoretical frame provided by NM and posthumanism will allow the interpretation of selected case studies - ASMR videos published on YouTube - through the prism of vitality of the matter participating in the process of creating an artistic work "live", during the interaction between the human artist and the material accessories and technological machines used in videos. The article wants to answer the question: What does the creative cooperation between human and non-human factors look like in a given ASMR artwork? - how it manifests itself, how it can be conceptualized, what the consequences are (including ethical consequences that involve our relationship with the world). This article will, therefore, see creativity as the creativity of human and non-human matter interwoven, or as the result of metaphorical friction (which, as we will find out later, often takes form of quite literal rubbing of objects and people against each other) of human and non-human bodies, the entanglement that results in a new quality whose components cannot be easily separated. 
The research material analyzed in the article will consist of selected popular ASMR videos published on well-known and highly viewed YouTube channels, often with hundreds of thousands of views. Since there are thousands of ASMR videos published online, we can focus only on those selected examples which, in our opinion, support the thesis about cooperation of human and non-human matter - in other words, the constant game of various creative players, their influence on each other and participation in producing the final effect, i.e. creating a given artwork that is supposed to affect viewers in many different ways - from the tingling sensation on the scalp, known as "brain tingles", to the feeling of total relaxation and drowsiness. The analyses will start with defining the ASMR phenomenon and identifying those of its qualities and properties we find most important, corresponding to the ideas developed within posthumanism and NM regarding the creativity of matter. The article will also show the categories used by the few researchers of cultural aspects of ASMR to interpret this phenomenon - what they focus on and why. Next, the text will move on to presenting different types of creativity in ASMR and analyzing the research material to look closely at the relationship between human and non-human matter. Generally, the author will try to contribute as thoroughly as possible to answering the question about a new type of posthumanist, neo-materialist creativity emerging within the studied phenomenon.

\section{What is autonomous sensory meridian response?}

In the context of online space, ASMR is a fairly new phenomenon. Its popularity has been growing rapidly for several years, but it has yet to have a spectacular number of serious scientific analyses. What is spectacular is the number of sensational and popular science articles focusing on the controversial aspects of the phenomenon called "braingasm", or "brain orgasm", in a way that is definitely "a little misleading" (Young \& Blansert, 2015, p. 12). The authors of such superficial analyses focus on the alleged sexuality inherent to ASMR videos as if they were simply full of bodies of beautiful, alluring young girls who both made the videos and act/perform in them. ASMR is sometimes even ambiguously referred to as " $\mathrm{a}$ quirky version of online porn" (Sadowski, 2016, p. 158), despite the strong voices from the ASMR community that their videos have no strong sexual connotations.

There are very few studies that analyze the ASMR phenomenon from a cultural perspective, especially if we are talking those using the theoretical and conceptual framework from the forge of posthumanism or NM. What might be additionally striking is the fact that, when going through all the research on this phenomenon, it is difficult to come across any attempts at conceptualization of the idea of creativity in ASMR. Researchers quite often describe ASMR in the context of feminist or gender studies, focusing on female representation in videos, claiming that women are by far the largest group among the creators of ASMR videos. For example, Sadowski (2016) uses Laura Mulvey's theory of male gaze in cinema known from the famous paper, "Visual Pleasure and Narrative Cinema" (Mulvey, 1975). Instead of focusing on the materiality of human and non-human subjects, and posthumanist creativity, Sadowski's dissertation focuses on various forms of online abuse and cyberbullying against women and on the meanings of female representation in cyberspace - and that is also the context for her brief analysis of ASMR videos. Other researchers look at this phenomenon 
from the perspective of performance studies and affect theory, elaborating on new definitions of sexuality and pleasure in postmodernity, as well as the qualities and chances of building digital intimacy - mediated by technology and going beyond the sphere of privacy (Waldron, 2017; Smith \& Snider, 2019). The so-called "nonstandard intimacy", the term coined by Berlant and Warner (1998), sometimes serves as a key concept for viewing the ASMR practices (Andersen, 2015). The phenomenon is sometimes analyzed using ideas developed within the framework of affect theory studies interpreting ASMR videos as "charged" with affectivity, which "thwarts linguistic articulation and rational comprehension" (Gallagher, 2016). In addition, researchers often focus on selected individual elements of the aesthetics of ASMR videos, e.g. on the whispering (Andersen, 2015) and the voice of female artists (Iossifidis, 2017), on the sonic aspect of videos whose sound compositions are called "a new kind of music" (Rice, 2016), and on the visual aspect that can be extremely sophisticated, well thought-out, and carefully planned.

What is the ASMR then? This phenomenon is based on a very specific sensation of tickling or tingling that begins on the scalp and then moves down the neck zone and towards the spine. It can often cover the whole body, moving around it like a pleasant shiver. Those who have experienced this sensation describe it as an extremely relaxing, comfortable, and pleasant feeling that can calm you and your thoughts down, improve your concentration and sleep, and significantly enhance your well-being. ASMR can be caused by a number of factors. The most common include auditory, visual, olfactory, and tactile stimuli. People attending an ASMR session are exposed to the stimuli mentioned above, which are provided by the artist running the session. Such an individual or group session can be conducted live in a special place similar to a wellness center, specially designed for the recipient and tailored to their needs to ensure relaxation of body and mind. However, the most popular form of ASMR content among the Whisper Community, or the community watching and creating ASMR content, are videos posted online and it is the videos that attract interest of researchers.

The name "ASMR" stands not only for that specific tingling sensation, but for an entire cultural phenomenon characterized by a crop of videos showing ASMR techniques, designed to make the best use of various stimuli that can cause a pleasant tingling sensation in the viewers' bodies. The videos, carefully directed and edited, can contain some typical ASMR scenes such as: role playing (e.g. visiting a beautician, a hairdresser's, a SPA), speaking to the viewers in a whisper, using selected props, eating various products, etc. The scenes usually have the form of a directed performance which includes the best techniques of stimulating the viewer-listener who has the impression of interacting with the ASMR artist in an intimate and sensual private meeting full of stimuli and pleasant sensations. ASMR artists care about the appearance of an intimate relationship with the viewer-listener of the session which is supposed to be therapeutic, relaxing, and beneficial for the body and mind.

What is additionally striking is how rarely people point out that the ASMR phenomenon somehow corresponds with the ideas of the posthuman and new materialist breakthrough we can see in today's humanities, social sciences, and cultural studies, especially in the context of formulating a new approach to objects and their agency, activity, and impact on people and the world around us. The ideas of posthumanism and NM, especially the postulate of moving away from the fundamentally narrowing anthropocentric, traditionally human per- 
spective, have practically become a new, binding paradigm in approaching the examination of our reality. ASMR videos adopt a new individual approach to the matter we and other elements of the world are composed of. Artists, using various gadgets, artefacts, and props in their performances, emphasize their material, physical characteristics and properties - both the obvious ones, associated with the object's utilitarian, customary purpose, as well as those properties that are unusual, completely imperceptible at first glance, those that go beyond rational judgment. Objects used in videos as props that cause the viewers' shivers (e.g. hair brushes, plastic shopping bags, hardcover books, latex gloves, bubble wrap, gift wrapping paper, adhesive tape - to name a few popular triggers) are treated as material elements creating a new posthuman subject-assemblage together with the human subject, characterized by creativity visible in an "interplay of human and nonhuman agency, a dance of agency" (Pickering, 2008b, p. vii). Posthuman creativity is born in this dance of agents, creative human and non-human actors composed of matter. We see ASMR techniques as fitting into the new materialistic perspective that suggests "we are neither particularly powerful nor especially intelligent and creative - at least not on our own" (LeCain, 2017, pp. 314-315). We interpret the ASMR artistic practices as something that shows this type of new approach to the world and creative art, approach that is related to the new materialist one, which "suggests that we humans derive much of what we like to think of as our power, intelligence, and creativity from material things [...]" (LeCain, 2017, pp. 314-315). It is time to look at individual cases of creative cooperation between humans and non-humans in ASMR.

\section{Objects on a pedestal: sensual creativity}

Creativity in ASMR has many different faces. One of those that are most visible at first glance is when an ASMR artist works with various objects, called "triggers", used to create sound effects that are supposed to give the viewer pleasant shivers. All you need is to watch a couple of random videos made by ASMRtists to understand what a wide range of resources and a huge group of props designed to have a beneficial effect on viewers are used. The artists' imagination seems to have no limits here. The number of artefacts used in the videos is so large that we can be almost certain that after searching "ASMR" and a name of a completely random object that comes to mind (e.g. "book", "table", "photo album", "carrot", "cassette tape", etc.) on YouTube, we will get a substantial amount of search results which will certainly include the videos we want with the objects in question. Artists compete in searching for more and more interesting items that can astonish both them and the viewers with their interesting hidden, mainly sonic, but also visual properties, as well as those that in a way appeal to the senses of touch or smell. The author of the "Caroline ASMR" channel, which has over half a million subscribers, in her video entitled "ASMR 10 Scratching Triggers to Help You Sleep and Study" (YouTube, 2018b), combines objects that seem to have nothing in common. You will see (and, of course, hear) a basketball, a konjac sponge for face washing, an archaeology kit for kids allowing you to dig up a dinosaur skeleton, a sequined cushion, an $\mathrm{iPad}$ case made of leather-like material, among others. The artist scratches the surfaces of objects which brings out some interesting sounds making the viewer feel (or not feel) pleasant chills, and as a result, the viewer can focus on learning or just falling asleep. 
Caroline approaches objects and their physical properties with astonishment that, according to Bennett (2010), would characterize a child learning about the world. In fact, "childlike reception of the world is helpful in facilitating a better understanding of the vitality of things" (Hood \& Kraehe, 2017, p. 34). Caroline's approach to the props she uses in the video makes her similar to a discoverer of fascinating unknown lands. She treats objects as if she had never seen them before and wanted to get to know all of their qualities and properties that are invisible at first glance. The artist takes an artefact in her hand and tactilely examines it for a moment, its weight, texture, roughness, etc., out of desire to look beyond its utilitarian, well-known, common sense application. She does not use the sponge to wash her face, but as a toy that fits perfectly in her hand, caressing it with its rough texture, a toy that, when gently scratched with nails, produces a crispy, soothing sound. The basketball is not used for playing, but becomes a kind of musical instrument emitting deep and intense tones. The pillow is not used for sleeping or as a decoration, but, when scratched with nails and touched with fingers, it makes rustling and crunching sounds, while glittering with the colors of the rainbow. And so on.

When you open yourself to the materiality of objects with a certain dose of "childlike sense of wonder" (Hood \& Kraehe, 2017, p. 34) you put them in the center of attention, on the pedestal. One of the comments under a YouTube video titled "ASMR 1 Hour Sound Assortment to Make You Sleep (No Talking)" published on the "ASMR Bakery" channel addressed to the creator of the video, said: "You handle every item so carefully. It's like they are artifacts you don't wanna break [...]" (2018a). The video in question shows the artist carefully tapping slow melodies with her nails on a glass bottle of nail polish, a makeup brush, tweezers, and a cardboard box - every single tap is celebrated. The ASMRtist gives the impression that she is just learning about the sound properties of these objects and their matter - as if she was hearing them for the first time or only now stopped in her tracks and paid more attention to what she has been missing so far. This typically posthuman and new materialist renewal of our relationship with the materiality of the world encourages reflection on the concept of creativity which is born here out of a truly childlike bewilderment at the world and our conscious acceptance of the activity of non-human, material players in the process of creating a work of art "live". According to Bennett, "vibrant matter is not the raw material for the creative activity of humans or God" (2010, p. xiii). An artist works with matter that wants interaction and, on the way, reveals some potentialities activated under the influence of touch, friction, nail scratching and other activities, while such activity does not involve any assumed purposefulness. Objects used in ASMR are like "materialities that are active and creative without needing to be experienced or conceived a partaking in divinity or purposiveness" (Bennett, 2010, p. 93). Creativity in ASMR is a combination of potentiality of human and non-human matter. We can imagine it as a dance of the immanent possibilities of both matters, that are rubbing against, circling around, and examining each other, illuminating their features, but with no particular direction. ASMR artworks emphasize the importance of attentive interaction with the materiality of objects from our everyday life, objects that often seem transparent to us.

The childlike perception of the world offered in ASMR is mainly sensual. Maria Viktorovna, who runs an extremely popular channel, "Gentle Whispering ASMR", often tries to 
carry out a massive attack on all senses of the viewer in a single video by using, for example, multi-colored lighting for the background and props, big close-ups of objects and parts of her body, different points of view of the camera, as well as breaking the fourth wall, e.g. putting her arms round the camera, touching it from both sides as if it was a head, whispering into the microphone located where the viewer's ear should be, etc. The video called “... Fast Tapping Extravaganza $\bullet$ ASMR • Sensory Stimulation • No Talking •” (YouTube, 2019b) shows the colors of objects and their lighting that change kaleidoscopically to give the viewer a large number of stimuli. Viktorovna is tapping the camera eye with her fingers, stroking it so that the viewer almost feels the touch of her hand on their skin, and then, she is rubbing her hand very close to the microphone, producing an even more intense sensation of rubbing her skin against ours. The sensual creativity we witness in ASMR is a synesthetic translation of sensations, e.g. mixing of visual and sound sensations with tactile ones. By acting on the viewer's sense of sight and hearing, the artist often activates their sense of touch. Studies have revealed that physiological reactions triggered in people experiencing brain tingles while watching ASMR videos, apart from reduced heart rate, include increased skin conductance level (Poerio et al., 2018). This is closely related to the feeling of being touched by the artist's hands, but also to the transposition of the feeling of touching the artifacts the performer is playing with.

Laura U. Marks, a famous media theorist, once introduced a concept of haptic visuality useful for studying media messages, which focuses on the possibility of multisensory reception of a certain work of art and its multisensory dimension, including its tactile or olfactory level (2000). The Marks' theory presents our eyes as a metaphorical organ of touch, used to feel both our corporeality and the physicality of the artwork and its matter (2000). According to Sadowski, haptic images in ASMR include "grainy close-ups that are 'too close to see' from an objectivizing outside" (2016, p. 185) that invite the viewer to turn on the multisensory mode to take in the artwork. The close-ups of the artist's body parts, which do not give in to the universal perspective that wants to take them all in, are haptic images that pull us close. According to Marks, those close-ups are also one of the ways a film can appeal not only to the sense of touch, but also to the sense of smell. Other methods described by the researcher include the viewer's identification with the person on the screen sniffing something or by using sound, often combined with a close-up, so we can almost feel the smell filling the scene. ASMR is, of course, full of this type of techniques. One of the videos stars Viktorovna who is showing the viewers her collection of perfume, spraying the cosmetics into the air, moving fragrance test strips close to the camera, whispering in a convincing and soothing tone: "It's a very beautiful scent" (YouTube, 2018d). Another artist, shot from a medium distance, is slowly spilling coffee beans from a bag onto a table, and then, moving them between her fingers, producing some appetizing and crispy sounds which can also evoke some smell associations (YouTube, 2015). These types of haptic images encourage the viewer to examine them with all their senses, not only with the seemingly superior senses of vision and hearing (Marks, 2000).

The creativity of ASMR artists when producing this type of haptic images without regard for the eternal primacy of sight in Western culture is astounding. Starting with the dismemberment of the body shown on the screen, e.g. showing only hands or the whispering lips, through extreme close-ups of various objects, often difficult to identify at first glance, e.g. 
brush hairs scratching the microphone and entering the grille's spaces; to the viewer being completely cut off from any visual stimuli, e.g. filming the video in total darkness to sharpen the other senses. These types of experiments are supposed to surprise the viewer and pull their body into an affective vortex of sensations produced by unusual stimuli. Born out of the meeting of human and non-human matter, sensual creativity in ASMR focuses, therefore, on the appreciation of the multisensory experience of the world in a way that allows you to notice the post-human, non-rational, material element of our existence.

\section{Tingling machineries: techno-creativity}

ASMR videos are a great example of artistic activity that shows involvement of different elements: both human-biological and artificial-technological. What we refer to as "techno-creativity" means the creativity resulting from the interaction of man and all kinds of machineries used when making those videos. They mainly include different types of microphones, cameras, headphones, as well as image and sound editing software. The concept of technocreativity does not see the autonomous, creative, human self as the most important part of the artwork creation process anymore. Techno-creativity is posthuman creativity where the human factor interacts with technological instruments in the creation process, which means that those of the artist's decisions that contribute to the final shape of their work are closely related to the machines surrounding the artist.

This type of cooperation between humans and technical background elements in the creative process used to favor the human factor over technological instrumentation. As an individual who is able to think, feel, and create, the human was still the one who seemed to influence and shape matter as they wished. The role of various instruments and materials in this creation process was highly underappreciated and limited mostly to transparent assistance for the artist, as well as an invisible component of the final work.

We have to agree that ASMR videos, these shiver-inducing machines, could not exist if it was not for the close cooperation of humans and the new technological solutions adapted by them. Despite the fact that most of ASMR videos look like amateur recordings, created hastily, live, spontaneously, they are actually extremely well thought out and their structure, aesthetics, composition, etc. are the result of long hours of work - from planning the use of props, through choosing the location, settings of camera and microphones, to recording and editing of the material. A lot of artists make videos for life, so they take it very seriously, do it with passion and commitment. The machinery used in ASMR videos is not transparent and the technical means used by the artist do not disappear from view immediately after the work is complete, on the contrary - they play a leading role in the whole process. All you need to do is to search "ASMR microphone scratching" or "ASMR microphone brushing" on YouTube to get thousands of results showing videos of one of the most popular triggers in ASMR circles. One of the videos shows an artist scratching a microphone sponge using various objects: scissors, forks, a hair comb, toothpicks, makeup brushes (YouTube, 2019d). Another video shows a performer covering a metal microphone grille with various kinds of sticky substances, the so-called slime, only to slowly and solemnly detach them from the device - all in search of unusual sounds, of course (YouTube, 2018c). Another equally popular 
type of videos involves stroking, scratching, and caressing of the camera located where the head of a potential viewer would be. They include a video where the performer plays the role of a make-up artist putting cosmetics on the viewer's face (i.e. on the camera) with a brush, then measuring their head with a measuring tape and looking into their ears using a small flashlight (YouTube, 2019a).

A traditional film never shows technical equipment on purpose, but ASMR videos usually put it right in the center, both literally on the set (e.g. microphones positioned at the bottom center of the screen), as well as when creating the language of the medium itself and giving the final shape to the artwork (after all, it is mostly the microphone that conditions the quality of sound that will reach the viewer and the sensation it will produce). Microphones, called "the sonic equivalent of a magnifying glass" here (Garro, 2017, p. 397), appearing in various shapes and sizes, e.g. in the shape of human ears, are one of the elements allowing the viewer to fully immerse themselves in the ASMR world and facilitating the affective flow of vibrations between the bodies of the artist, the viewer, and the artifacts. The placement of microphones is another important issue. Some artists prefer to put two separate microphones where the ears of the potential listener could be, i.e. on both sides of the screen, and lean alternately to the right and to the left - as if they were whispering in the listener's ear (YouTube, 2019c). Others use binaural microphones, e.g. the distinctive 3Dio, which allow for creative play with polyurethane ears placed on both ends of the device. One of the popular videos shows ASMRtist who strokes, licks, kisses, massages or simply cleans the artificial ears with brushes, cotton swabs, sponges, dental accessories, glass pipettes and other items (YouTube, 2017).

Headphones are another important element of this technical universe. Artists often wear them during the filming so that they can hear exactly what the potential viewer will later hear in their headphones and so that they can control the performance as best as possible. In addition, artists often recommend using headphones to their viewers watching the videos, which is supposed to allow them to achieve a much clearer immersion effect and, consequently, easier relaxation than when listening to the sound flowing from laptop speakers.

These technological players are an undeniable creative element of the ASMR phenomenon. It is no coincidence that whispered live sessions have not gained even a fraction of the popularity of their technologically mediated siblings. The tools at the artists' disposal have a direct impact on how they implement the concept of creativity and, as a result, the idea of its posthuman side. It seems that, through their works of art, ASMR artists indirectly embrace the idea about both posthuman creativity and posthumanism in general. This is often manifested in their commitment to creative cooperation with technological instruments and their focus on non-human elements throughout the process. Brett wrote that "techno-creativity [...] is defined as the give and take relationship between musicians and their machines [...]" (2006, p. 5). In case of ASMR practices combining paths of new technologies and human creativity, we deal with the constant discovering of new lands ready to be explored by artists. The posthuman aspect of this process emphasizes both the artist's readiness to open themselves to the possibility of creative cooperation with technology and the re-appreciation of the materiality of non-human bodies inhabiting the world around us, as well as the significance of multisensory experiences. 


\section{Conclusions}

This article tried to answer the question of how you can conceptualize the idea of creativity emerging from the practices known from the cultural ASMR phenomenon that has been thriving in recent years in the online community active mainly on YouTube. The article put forward a thesis that creativity emerging from ASMR artworks can be called posthuman in the sense that ASMR works are created by both human and non-human factors. Such work of art is not a finished result of the vision of an artist who is independent of the world around them - quite the opposite. ASMR posthuman creativity - with sub-types like sensual creativity or techno-creativity described above - becomes a result of the interaction of humans and non-human bodies and the friction of matter everything is composed of.

The author believes the concepts taken from the theory of NM have turned out to be extremely useful in the conceptualization of the idea of creativity in ASMR. The activity of ASMR artists on YouTube shows an attitude to reality similar to the one of researchers adopting the philosophy of NM, especially those that appreciate the potential for the activity of various non-human players. ASMR activities are rooted in accepting the concept of thing-power and distributive agency, known mainly from the writings of Bennett, and the simple childlike delight in materiality and plasticity of the world. Artists, together with other-than-humans actants including both numerous objects used in performances as props in order to cause a pleasant tingling sensation in the body of the viewer, as well as complete technological equipment for making the video, force, maybe unconsciously, the ethics of symbiotic coexistence of humans and non-humans in our reality.

ASMR artists use a range of familiar accessories when filming their videos, focusing on their non-obvious qualities and properties that go way beyond the usual application. Posthuman creativity comes from exceeding the utilitarian approach to objects that are supposed to serve us in our everyday "dominion over the world". The artists look at the objects with fascination and amazement - as if they were seeing them for the very first time. They are learning their properties "live", during the affective interaction of bodies. They also use different methods to encourage the viewer to turn on the multisensory mode of receiving the work. Following the posthumanist paradigm, they emphasize non-visual (including sonic, tactile, and even olfactory) properties of the artifacts shown.

The discussion started with the question whether creativity is a solely human quality. The latest type of artistic activity that we can find in ASMR is like a lens that focuses the entanglement of activity of human and non-human matter. In the author's opinion, creativity in ASMR becomes a complex combination of activity of human and non-human matter, that, in a posthuman way, defies unambiguous classifications, mixes the established orders and provokes crossing the boundaries between them.

However, it should be stipulated that perceiving ASMR videos from the presented research perspectives cannot overshadow other scientific angles. Many essential elements of the ASMR universe remained unexplored in this article, such as the materiality of sounds celebrated in the soundtracks of the videos like in contemporary musique concrète pieces, or the existence of various popular culture discourses and schemes in ASMR role-play videos (e.g. science fiction discourse in which the viewer is cast as a broken robot repaired by the artist). Moreover, critical sleep studies - a currently emerging subfield of humanities and 
social science focusing on the representations of sleep, including its transformations into a digital commodity - offer a very exciting perspective possible to apply while analyzing ASMR. Perhaps posthuman creativity of ASMR is being put to the service of capitalism? Hence, further development within the research on ASMR is more than needed.

\section{References}

Andersen, J. (2015). Now you've got the Shiveries: Affect, intimacy, and the ASMR Whisper Community. Television and New Media, 16(8), 683-700. https://doi.org/10.1177/1527476414556184

Bennett, J. (2010). Vibrant matter: A political ecology of things. Duke University Press. https://doi.org/10.1215/9780822391623

Berlant, L., \& Warner, M. (1998). Sex in public. Critical Inquiry, 24(2), 547-566. https://doi.org/10.1086/448884

Brett, J. Th. (2006). Minds and machines: Creativity, technology, and the posthuman in electronic musical idioms (PhD/Doctoral Thesis). ProQuest Dissertations Publishing.

Chappell, K. (2018). From wise humanising creativity to (posthumanising) creativity. In K. Snepvangers, P. Thomson, \& A. Harris (Eds.), Creativity policy, partnerships and practice in education (pp. 279-306). Series: Creativity, education and the arts. A. Harris (Series Ed.). Palgrave Macmillan. https://doi.org/10.1007/978-3-319-96725-7_13

Gallagher, R. (2016). Eliciting euphoria online: The aesthetics of "ASMR" video culture. Film Criticism, 40(2). https://doi.org/10.3998/fc.13761232.0040.202

Garro, D. (2017 11-13 July). Autonomous meridian sensory response - From internet subculture to audiovisual therapy. In Proceedings of the Conference of Electronic Visualisation and the Arts (EVA 2017). Conference of Electronic Visualisation and the Arts (EVA 2017) (pp. 395-402). Paris, France. https://doi.org/10.14236/ewic/EVA2017.79

Hood, E. J., \& Kraehe, A. M. (2017). Creative matter: New materialism in art education research, teaching, and learning. Art Education, 70(2), 32-38. https://doi.org/10.1080/00043125.2017.1274196

Iossifidis, M. J. M. (2017). ASMR and the "Reassuring Female Voice" in the sound art practice of Claire Tolan. Feminist Media Studies, 17(1), 112-115. https://doi.org/10.1080/14680777.2017.1261463

Kluszczyński, R. W. (2013). Towards posthuman creativity: From kinetic to bio-robotic art. In M. MrózGrygierowska \& T. Ekstrand (Eds.), Art line: A Baltic collaboration (pp. 94-101). Blekinge Museum.

LeCain, T. J. (2017). The matter of history: How things create the past. Cambridge University Press. https://doi.org/10.1017/9781316460252

Marks, L. U. (2000). The skin of the film: Intercultural cinema, embodiment, and the senses. Duke University Press. https://doi.org/10.1215/9780822381372

Mulvey, L. (1975). Visual pleasure and narrative cinema. Screen, 16(3), 6-18. https://doi.org/10.1093/screen/16.3.6

Pickering, A. (2008a). New ontologies. In A. Pickering \& K. Guzik (Eds.), The mangle in practice: Science, society, and becoming (pp. 1-14). Duke University Press.

Pickering, A. (2008b). Preface. In A. Pickering \& K. Guzik (Eds.), The mangle in practice: Science, society, and becoming (pp. vii-xiv). Duke University Press.

Poerio, G. L., Blakey, E., Hostler, Th. J., \& Veltri, Th. (2018). More than a feeling: Autonomous sensory meridian response (ASMR) is characterized by reliable changes in affect and physiology. PLoS One, 13(6), e0196645. https://doi.org/10.1371/journal.pone.0196645

Rice, Ph. (2016). "Oh Such a Good Sound": Remaking the world, or a case for a macrocosmic aesthetic of grace in ASMR. Zenodo. https://zenodo.org/record/258582\#.Xk_-kXduLaA 
Roudavski, S., \& McCormack, J. (2016). Post-anthropocentric creativity. Digital Creativity, 27(1), 3-6. https://doi.org/10.1080/14626268.2016.1151442

Sadowski, H. (2016). Digital intimacies: Doing digital media differently (PhD/Doctoral Thesis). Linköping Studies in Arts and Science No. 691. Linköping University. Linköping, Sweden. http://www.divaportal.org/smash/get/diva2:1047582/FULLTEXT01.pdf

Smith, N., \& Snider, A.-M. (2019). ASMR, affect and digitally-mediated intimacy. Emotion, Space and Society, 30, 41-48. https://doi.org/10.1016/j.emospa.2018.11.002

Turing, A. M. (1950). I. - Computing machinery and intelligence. Mind: A Quartertly Review of Psychology and Philosophy, 59(236), 433-460. https://doi.org/10.1093/mind/LIX.236.433

Waldron, E. L. (2017). “This FEELS SO REAL!" Sense and sexuality in ASMR videos. First Monday, 22(1-2). https://doi.org/10.5210/fm.v22i1.7282

Young, J., \& Blansert, I. (2015). ASMR: Idiot's guides. As easy as it gets! Penguin Random House LLC.

YouTube. (2015). Coffee beans means ASMR. Relaxing wood, crinkles and tapping sounds. https://www. youtube.com/watch?v=zX-EBA6e $388 \&$ feature $=$ youtu.be

YouTube. (2017). Twin ear cleaning that will make you tingle 150\% [22 mins] - ASMR. https://www. youtube.com/watch?v=qKHpcXUAQIM\&feature=youtu.be

YouTube. (2018a). ASMR 1 hour sound assortment to make you sleep (no talking). https://www.youtube. $\mathrm{com} /$ watch? $\mathrm{v}=18 \mathrm{hniYMLKdM \& feature=youtu}$.be

YouTube. (2018b). ASMR 10 scratching triggers to help you sleep and study. https://www.youtube.com/ watch?v=IlntNtfozpk\&feature=youtu.be

YouTube. (2018c). Slime in your ears for 30 minutes / ASMR. https://www.youtube.com/watch?v=coQzh8zO_c\&feature=youtu.be

YouTube. (2018d). Women's perfume emporium. ASMR • Soft Spoken • Liquids • Tapping • Clicky. https:// www.youtube.com/watch?v=UUOdiWO3qwI\&feature=youtu.be

YouTube. (2019a). [ASMR] visual triggers for sleep (personal attention) face brushing, measuring and light tracing. https://www.youtube.com/watch?v=_t_s6Lf8LZ0\&feature=youtu.be

YouTube. (2019b). Fast tapping extravaganza. ASMR • Sensory Stimulation • No Talking. https://www. youtube.com/watch?v=aqHglz3SfKM\&feature=youtu.be

YouTube. (2019c). ASMR ear to ear whispering + Intense mouth sounds. https://www.youtube.com/wat $\mathrm{ch} ? \mathrm{v}=\mathrm{HqBrIk} 32 \mathrm{~h} 7 \mathrm{Y} \&$ feature=youtu.be

YouTube. (2019d). ASMR mic scratching with sharp objects (no talking). https://www.youtube.com/ watch? $\mathrm{v}=\mathrm{r} 7 \mathrm{v}-\mathrm{uvnO} 1 \mathrm{zE} \&$ feature $=$ youtu.be

\title{
ŽMOGIŠKOS IR NEŽMOGIŠKOS MATERIJOS SAMPYNOS KÜRYBIŠKUMAS: AUTONOMINIO JUTIMO MERIDIANO ATSAKUI SKIRTI VAIZDO İRAŠAI POSTHUMANIZMO PERSPEKTYVOJE
}

\author{
Joanna ŁAPIŃSKA
}

\section{Santrauka}

Kūrybiškumo idejos problematizavimas lèmè tai, kad buvo iš naujo apsvarstytos koncepcijos, susijusios su savarankiška, kūrybiška ir žmogiška savastimi - tai tapo realybe baigiantis modernizmui ar net ir anksčiau. Postmodernizmas, kaip ir posthumanizmo bei naujojo materializmo teorijos, operuojančios tokiomis kategorijomis, kaip materialumas, virtualioji realybė, transgresija, hibridizacija ir kt., kelia tam tikrų ap- 
mąstymų dèl nežmogiško kūrybiškumo, kuris jau nebėra savybè, vidujai priskiriama žmogui, idejjos. Tai žmogiškų ir nežmogiškų elementų sąveikos rezultatas, apimantis emocinę materinių kūnų trintị. Straipsnyje, iš esmès paskatintame posthumanizmo, naujojo materializmo ir naujųjų medijų studijose plètojamų teorijų ir metodologijų, siekiama atsakyti ị klausimą, susijusị su kūrybiškumo rūšimis, kylančiomis naujojo YouTube reiškinio kontekste - su autonominio jutimo meridiano atsakui skirtais vaizdo įrašais, plačiai skelbiamais pastaraisiais metais. Šis straipsnis - tai pastangos išsamiai aprašyti posthumanistinio kūrybiškumo idèją, jam būdingus potipius, tokius kaip juslinis ar techninis kūrybiškumas, regimas ypač populiariuose, tačiau mažai tyrinètuose autonominio jutimo meridiano atsakui skirtuose meno kūriniuose. Straipsnyje pateikiama tezé, esą autonominio jutimo meridiano atsakas - tai pavyzdinis meno reiškinys, kuriame žmogiškos ir nežmogiškos materijos sampyna sukuria posthumanistinio kūrybiškumo formą. Buvo išanalizuota daugybẻ autonominio jutimo meridiano atsakui skirtų vaizdo įrašų, kuriuose pabrèžiamas specifinis kūrybinès žmogiškų ir nežmogiškų elementų sąveikos pobūdis. Daromos išvados, kad su autonominio jutimo meridiano atsaku susiję meno kūriniai tapo posthumanistinio kūrybiškumo produktu, kurio pagrindas yra abipuse emocinẻ kūnų sąveika.

Reikšminiai žodžiai: autonominio jutimo meridiano atsakas, naujasis materializmas, naujųjų medijų studijos, posthumanistinis kūrybiškumas, posthumanizmas, techninis kūrybiškumas, YouTube. 